\title{
PERAN CASE WORKER DALAM PENANGANAN ANAK YANG MENGALAMI KEKERASAN DALAM KELUARGA
}

\author{
Oleh: \\ Viqa Nanda Prajatami, Santoso T. Raharjo, \& Meilanny Budiarti S.
}

\section{PENDAHULUAN}

Negara Indonesia ialah negara yang memiliki dasar undang-undang yang kokoh, tetapi disisi lain banyak dari masyarakat Indonesia yang mengacuhkan peraturan atau undang-undang yang telah dibuat tersebut yang akhirnya berdampak kepada masalah sosial. Masalah sosial telah banyak di temui dan menimbulkan dampak buruk bagi bangsa, salah satu yang menjadi sorotan ialah kekerasan yang terjadi kepada anak dalam lingkungan keluarga. KPAI mencatat pada tahun 2014 terdapat 622 kasus kekerasan pada anak.

Sebagaimana yang kita ketahui bahwa anak merupakan aset atau harta orang tua ketika ia telah besar nanti juga sebagai penerus generasi bangsa di kemudian hari, jika kekerasan pada anak tidak diputuskan dari sekarang maka dapat berlanjut seperti mata rantai dan akan terus dilakukan dari generasi ke generasi karena anak akan belajar bahwa dengan cara kekerasan dibenarkan untuk memberikan anak pelajaran kedisiplinan dan ketika di usia dewasa anak akan menggunakan hal serupa untuk mendisiplinkan anaknya.

Selain pemerintah yang menangani kasus tersebut juga dibantu dengan lembagalembaga yang bergerak fokus dalam menangani kasus anak. Seperti Pekerja sosial pun masuk di dalamnya guna memberikan peran yang tepat ketika menangani kasus anakanak tersebut. Diantaranya adalah UNICEF, Save the Children, Komisi Perlindungan Anak Indonesia (KPAI), Lembaga Perlindungan Anak (LPA), Pusat Pelayanan Terpadu Perempuan dan Anak "Resko Dyah Utami" yang ada di Yogyakarta dan masih banyak lembaga lainnya yang turut membantu menangani kasus kekerasan pada anak. Seperti yang sudah dikatakan sebelumnya di dalam lembaga-lembaga tersebut terdapat pekerja sosial yang berperan penting dalam menyelesaikan masalah, sebagai contoh pekerja sosial dapat menjadi advokator menurut Departemen Sosial R.I BBPPKS (dalam Muhammad Iqbal) advokasi dalam pelayanan perlindungan anak adalah:

"Agar dapat membantu klien mendapatkan pelayanan yang dimanfaatkan sebagai sumbersumber yang dibutuhkan untuk mewujudkan hak-hak anak dengan cara melindungi martabat mereka, serta untuk mempengaruhi dan mendesakan perubahan dalam kebijakankebijakan praktek-praktek dan aturan-aturan yang akan menjamin terwujudnya hak anak secara menyeluruh."

Menurut Zastrow (1982) mengartikan advokasi adalah aktivitas menolong klien atau sekelompok klien untuk mencapai layanan tertentu ketika mereka ditolak suatu lembaga atau suatu sistem layanan, dan membantu memperluas pelayanan agar mencakup lebih banyak orang yang membutuhkan. Dengan demikian advokasi dibutuhkan ketika pemerintah kurang peka terhadap masalahmasalah tertentu, dan pekerja sosial dapat membantunya melalui mengadvokasi supaya hal yang merugikan dan berdampak negatif bagi masyarakat dapat dihilangkan.

Oleh karena itu perlunya peran pekerja sosial dalam mengatasi masalah kekerasan anak dalam keluarga karena pekerja sosial 
mempunyai kemampuan dasar diantaranya ialah body of knowledge, body of values, dan body of skill. Body of knowledge sendiri. Menurut Alfred Kadusin menjelaskan bahwa body of knowledge pada dasarnya terdapat 5 tingkatan yaitu yang pertama mencangkup pengetahuan pekerjaan sosial secara umum yang meliputi pelayanan dan kebijakan, tingkah laku manusia juga lingkungan, metode-metode pekerjaan sosial kemudian kedua mengenai pengetahuan spesifik dalam bidang praktek, yang meliputi badan-badan koreksional seperti lembaga permasyarakatan, balai permasyarakatan, rumah tahanan. Ketiga ialah pekerja sosial mengetahui mengenai badan-badan sosial yang dapat membantu memberikan pelayanan terkait dengan klien, keempat ialah pengetahuan spesifik mengenai klien seperti family constellation, court contact, clinical, cottage report, scholl report dan medical report.Kelima ialah pengetahuan spesifik mengenai kontak yaitu relasi yang dijalin dengan baik, baik pada klien juga oangorang yang bepengaruh terhadap diri klien. Selanjutnya terdapat body of values yang mana pekerja sosial bekerja menggunakan nilai-nilai pribadi pekerja sosial, nilai profesi pekerja sosial, dan nilai klien. Terakhir ialah body of skill, kemampuan pekerja sosial dalam mengaplikasikan pengetahuan dan nilai yang telah di dapat memberikan jalan tebaik bagi klien.

\section{Metode Penulisan}

Metode yang digunakan dalam penulisan karya tulis ilmiah ini menggunakan metode penelitian deskriptif. Data dan informasi yang di dapatkan merupakan data-data yang ada melalui dokumen elektronik juga buku-buku dan jurnal ilmiah. Selain itu terdapat tahapan dalam melakukan penulisan ini yaitu dengan merumuskan masalah supaya mendapatkan gagasan setelah mendapat gagasan masuklah ke pengumpulan data dan fakta di lapangan kemudian menganalisa antara konseptual dengan data yang di dapatkan, setelah itu masuk kedalam perumusan hasil gagasan dan kesimpulan mengenai masalah tersebut.

\section{TELAAH PUSTAKA}

Kekerasan pada Anak

Anak merupakan anugerah dan karunia dari Tuhan Yang Maha Esa yang seharusnya kita jaga dan dibesarkan dengan baik. Akan tetapi pada kenyataannya banyak dari orang tua ternyata belum memahami bagaimana cara mengurus anak yang baik dan benar, tak jarang orang tua salah mengartikan apa yang ingin disampaikan dengan perbuatan yang dilakukannya. Sebagai contoh orang tua ingin membuat anaknya tersebut patuh dan disiplin tetapi cara penyampaian supaya anak tersebut dapat patuh dan disiplin menggunakan caracara yang kuang tepat seperti melakukan tindak kekerasan baik verbal maupun nonverbal. Hal tersebut dianggap benar sehingga dilakukannya terus-menerus. Hal tersebut disebabkan karena anak pada masa kecilnya mendapatkan tindak kekerasan dari orang tuanya dan hal tersebut kembali dilakukan olehnya ketika anak tersebut telah beranjak dewasa.

Dampak yang ditimbulkan karena kekerasan menurut Moore dalam Fentini Nugroho (1992:41) ialah dapat dijadikan dalam beragam katagori yang mana anak tersebut dapat menjadi negatif, agresif ataupun dapat menjadi pasif dan mudah frustasi akhirnya dapat menjadi apatis, yang membuatnya tidak memiliki jati diri, dan mereka tidak mampu menghagai dirinya sendiri, ada pula yang akhirnya sulit untuk dapat menjalin relasi dengan orang lain.

Peran yang diberikan orang tua yang seharusnya memberikan pengertian, kasih sayang, dan memberi rasa aman untuk anak tidak dapat berjalan baik. Untuk menghasilkan efek jera pada pelaku tindak kekerasan maka undang-undang mengenai perlindungan anak memberikan sanksi pidana terhadap segala bentuk kekerasan dengan ancaman minimal 10 tahun penjara. Hukuman tersebut dianggap adil karena yang menjadi korban ialah anakanak.

Sistem kesejahteraan anak meliputi berbagai layanan (misalnya,layanan berbasis keluarga, 
perlindungan anak, penempatan diluar rumah, layanan adopsi), meliputi pencegahan, intervensi, dan pengobatan. Layanan dimaksudkan untuk melindungi anak-anak dan kesejahteraan mereka, memperkuat keluarga, dan memberikan keabadian ketika anak-anak tidak dapat dengan aman tetap dengan keluarga mereka. Layanan kesejahteraan anak harus kekuatan berdasarkan; keluarga berpusat; trauma informasi; dan hormat dari keluarga budaya, nilai-nilai, kebiasaan, keyakinan, dan kebutuhan (Anak Liga Kesejahteraan of America, 2005).

\section{Peranan pekerja sosial}

Pekerja sosial pada hal ini turut andil dalam menangani kasus kekerasan pada anak. Salah satu peran yang mengatasi masalah tersebut ialah pekerja sosial sebagai advokator yang mana pekerja sosial melakukan tindakan yang mewakili klien untuk dapat memperjuangkan hak-hak dari klien tersebut karena klien tidak mampu bergerak sendiri dan terdapat kondisi yang mempersulit klien untuk mendapatkan sumber-sumber yang ia butuhkan.

Para pekerja sosial kesejahteraan anak juga harus memiliki pengetahuan kerja terkait dengan anak dan pengembangan dewasa, dampak trauma, orangtua dan keluarga dinamika, dan sistem masyarakat di mana anak dan keluarga berada. Selain itu, pekerja sosial kesejahteraan anak akan memiliki kemampuan terbukti untuk menerapkan pengetahuan ini untuk tepat campur tangan dalam keluarga, organisasi, dan sistem sosial. Intervensi ini akan membantu untuk mengatasi kebutuhan anak-anak dan keluarga. Intervensi juga harus bertujuan untuk mencegah kerusakan pada anak dan memaksimalkan peluang keluarga untuk fungsi dan stabilitas positif.

Menurut Schneider dan Lester advokasi dalam konteks pekerjaan sosial ialah sebagai perwakilan eksklusif dan timbal balik untuk klien atau beberapa klien atau pun untuk sebuah perkara dalam sebuah forum, upaya sistematik untuk mempengaruhi pengambilan keputusan dalam sistem yang tidak adil atau tidak responsif.Sedangkan menurut
Sheafor dan Horejsi, tindakan advokasi bertujuan untuk membantu klien dalam menegakkan hak-hak mereka untuk menerima sumber-sumber dan pelayanan-pelayanan atau untuk memberikan dukungan aktif terhadap perubahan-perubahan kebijakan dan programprogram yang memiliki efek negatif pada klien baik secara individual maupun kelompok.

Peran pekerja sosial dalam advokasi sosial advokasi adalah tindakan yang mendukung hak-hak individu atau masyarakat melalui intervensi atau pemberdayaan (Barker, 2003).

Terdapat langkah-langkah dalam melakukan advokasi diantaranya ialah:

a) Perumusan masalah

b) Diagnosis situasi orang-orang, struktur, atau sistem yang perlu diubah

c) Analisis kekuatan-kekuatan yang mendorong perubahan dan keuatankekuatan yang melawan perubahan

d) Identifikasi tujuan spesifik

e) Memilih strategi aksi sosial untuk mencapai tujuan

f) Membuat jadwal untuk melaksanakan rencana aksi

g) Pelaksanaan, monitoring dan evaluasi, dan rencana aksi berikutnya

Menurut Adi Fahrudin dijelaskan bahwa advokasi pekerjaan sosial itu terdiri dari beberapa komponen yaitu:

\section{Ekslusif (exclusive)}

Ekslusif menjelaskan bahwa hubungan antara klien dan advokat yang menunjukkan hubungan tersebut hubungan tunggal, unik, terfokus kepada klien,tanggungjawab utama kepada klien, dan berpusatkan kepada kebutuhan manusia. Ini berarti bahwa kebutuhan klien diberi prioritas yang utama bagi advokat, semua aktivitas, strategi, dan taktik secara spesifik di desain untuk memenuhi kebutuhan klien.

2. Timbal balik (mutual) 
menjelaskan hubungan antara klien dan advokat sebagai hubungan timbal balik, saling ketergantungan, kesamaan, bersama,berbagi tahap hubungan satu sama lain, pertukaran gagasan dan merencanakan bersama-sama, dan memiliki kebersamaan satu sama lain. Hubungan timbal balik (mutual) bermaksud bahwa advokat tidak mendominasi atau menyusun agenda untuk klien sebab kebutuhan klien diberi perhatian yang khusus. Advokat bekerjasama dengan klien, dan mereka memprosesnya sesuai dengan kesepakatan yang disetujui bersama-sama. Termasuk dalam terma hubungan timbalbalik (mutual) ini adalah pemberdayaan (empowerment) sebagai nilai pekerjaan sosial utama. Seringkali klien dengan masalah yang mereka alami akan merasa tidak berdaya, advokat perlu menjalankan aktivitas pemberian sokongan kepada kliendan mendorong mereka agar keluar dari masalah ketidakberdayaan mereka (Johnson, 1995; Taylor, 1987).

\section{Representasi}

Terma ini adalah berkaitan orientasi tindakan dan menjelaskan aktivitas advokatdengan berbicara, menulis, atau bertindak bagi pihak lain, berkomunikasi ataupernyataan kepedulian terhadap klien.

\section{Klien}

Dalam advokasi pekerjaan sosial, seorang klien (klien) mendelegasikan kepada pekerja sosial untuk bertindak atas dirinya yaitu representation

sebagaimana yang disebutkan di atas. Klien (klien) mungkin individu perseorangan, kelompok kecil atau besar, persatuan masyarakat, populasi etnik tertentu, individuindividu dengan kesamaan karakteristik dan kepedulian. Kadangkala, advokat mewakili seorang individu, namun bertindak bagi pihak kelompok yang mempunyai kesamaan atau kemiripan dengan individu yang diwakilinya. Klien dalam hal initidak terbatas kepada ukuran dan jumlah. Advokat dapat bekerja dengan semua klien, dari orang perseorangan hingga kepada persatuan dan kelompok masyarakat yang lebih besar.

\section{Masalah/penyebab}

Masalah biasanya isu tunggal, kondisi, atau masalah yang menyebabkan sejumlah orang berminat dan mendukung. Menurut Kotler (1972), ada tiga jenis penyebabya itu:

(1)helping cause, masalah pertolongan dimana advokat mencoba memberikan pertolongan, kenyamanan, atau pendidikan kepada korban kesalahan bantuan sosial termasuk rumah perlindungan (shelter) bagi wanita korban kekerasan atau perlindungan kepada lanjut usia,

(2)protest causes, tindakan protes, dimana advokat mencoba mereformasi institusi yang menimbulkanmasalah sosial, mempersoalkan tingkah laku baru untuk memperbaiki kondisi,contohnya rehabilitasi lingkungan pemukiman kumuh, atau menuntut agar pemerintah mengalokasikan dana untuk pelayanan kesehatan mental berbasis masyarakat,

(3)revolutionary causes, dalam hal ini advokat berharap dapat mengurangi institusi atau pihak-pihak yang tidak mendukung perbaikan kondisi.

\section{Forum}

Sebuah forum adalah majlis yang diorganisir untuk mendiskusikan isu, undang-undang, peraturan-peraturan, ketentuan-ketentuan, masalah publik, atau penyampaian opini. Advokat pekerjaan sosial selalu menggunakan forum dalam mewakili atau bertindak bagi pihak kliennya. Umumnya forum dikenali sebagaidengar publik, komite legislative atau sub komite, komite khusus, panitia kerja,dengar adminsitratif, komite kebijakan organisasi, rapat dewan pelaksana,pertemuan supervise, pertemuan staf organisasi, tribunal rakyat, dan lain sebagainya. Dua hal yang perlu dilakukan untuk melaksanakan forum seperti iniyaitu: (1) menetapkan seperangkat prosedur yang memandu peserta, (2) mekanisme pembuatan keputusan (Kutchin \& Kutchin, 1987).

\section{Sistematika}


Advokasi pada dasarnya bersifat sistematik. Hal ini karena advokasi menerapkan pengetahuan dan keterampilan dalam suatu perencanaan. Keputusan tidak didasarkan kepada intuisi melainkan berdasarkan keterampilan menganalisis situasi bersama klien.

\section{Pengaruh}

Pengaruh bermaksud modifikasi, perubahan, kesan, tindakan atau keputusan yangmempengaruhi klien. Beberapa aktivitas mempengaruhi termasuklah mengorganisir kelompok klien, pembentukan koalisi, pendidikan publik, persuasi kepada administrator dan supervisor, berhubungan dengan pegawai pemerintahdan parlemen, pengumpulan data kajian, pemberian testimoni, pengembangan petisi, dan bahkan tindakan undang-undang (Hepworth, et. al., 1997).

\section{Pembuatan keputusan}

Terma ini merujuk kepada usaha mempengaruhi. Paling utama adalah advokat ingin melakukan perubahan dengan membuat keputusan berdasarkan rumusan dan penilaian mengenai berbagai aspek seperti alokasi sumber daya, keuntungan,kelayakan, dan akses pelayanan. Keputusan ini bisa berbentuk sangat formal yaitudibuat berdasarkan prosedur dan amanat peraturan yang ada, manakala ada pula yang bersifat informal tergantung kepada koneksi pribadi, masyarakat, dan keluarga.

\section{Tingkat ketidakadilan}

Karakteristik terma ini adalah suatu tindakan, pendirian, institusi, peraturan, prosedur atau keputusan tidak sesuai dengan undang-undang atau prinsip-prinsip keadilan.

\section{Tidak responsive}

Terma ini khususnya diterapkan kepada perorangan atau institusi yang gagal menjawab, mengakui, atau merespon terhadap pertanyaan, permohonan, petisi,tuntutan, surat, komunike, atau permohonan sesuai dengan masanya

\section{Sistem}

Dalam kontek pekerjaan sosial, perkataan sistem merujuk kepada badan yang teroganisasi yang didesain dan bertanggungjawab untuk memberikan pelayanan kepada orang-orang yang layak, mendistribusikan sumber, penegakan hukum dan bertanggungjawab penuh dalam interaksi masyarakat dengan sistem sumber. Sistemsistem tersebut dapat berupa sistem pengadilan kriminal, sistem jagaan kesehatan, dan sistem transportasi. ${ }^{11}$

Para pekerja sosial kesejahteraan anak berusaha untuk mengadvokasi sumber daya dan reformasi sistem yang akan meningkatkan pelayanan untuk anak-anak, pemuda, dan keluarga. Dari sisi Lembaga kesejahteraan anak juga harus memastikan bahwa informasi mengenai undang-undang baru dan peraturan federal disebarluaskan dan menjelaskan kepada staf pada waktu yang tepat.

Para pekerja sosial harus menggunakan keterampilan dan pengetahuan mereka untuk mengadvokasi kesejahteraan anak, pemuda, dan keluarga mereka. Advokasi ini termasuk membantu klien untuk mengakses dan mengefektifkan penggunaan sumber daya formal dan informal di masyarakat yang mempermudah untuk advokat. Upaya advokasi juga harus diarahkan untuk memperbaiki kebijakan administratif dan publik untuk mendukung anak-anak dan keluarga mereka supaya tidak terjadi lagi kekerasan dalam rumah tangga. Upaya advokasi harus menekankan kekuatan dan aset pendekatan dalam pengembangan layanan sosial dan program-program kesejahteraan anak dan penggunaan praktik dan kebijakan berbasis pada bukti di lapangan.

Bedasarkan tulisan diatas maka peneliti menyimpulkan bahwa perlunya peningkatan pelayanan dan mempermudah sumber-sumber

\footnotetext{
${ }^{11}$ Adi Fahrudin, Advokasi Pekerjaan Sosial, STKS
} 
yang dapat membantu menghentikan tindak kekerasan dalam wilayah keluarga khususnya anak.

\section{SIMPULAN}

Kasus kekerasan anak pada keluarga merupakan kasus yang sepeti gunung es terbalik. Kasus yang tampak di permukaan hanya segelintir saja tetapi pada kenyataannya kasus seperti ini telah banyak terjadi dan dialami oleh anak-anak.Pekerja sosial pun harus dapat melihat dengan jeli akan kasus ini supaya dapat tertangani dengan baik dan kasus kekerasan pada anak tidak terjadi lagi di kemudian hari.

Pekerja sosial pun dapat terus membangun pengetahuan dan keterampilan mereka untuk menyediakan layanan yang baik untuk saat ini, menguntungkan, dan berbasis dengan mempelajari mengenai budaya-budaya yang sesuai untuk anak-anak dan keluarga yang terlibat dalam tindak kekerasan supaya akhirnya dapat terjalin kesejahteraan anak.

\section{SARAN}

Untuk mehadapi anak yang mempunyai kasus dengan kekerasan domestik maka pekerja sosial diharapkan dapat lebih cepat tanggap dalam menangani kasus seperti ini karena anak merupakan aset generasi bangsa, jika anak terus mendapatkan perlakuan tidak menyenangkan khususnya dari orang tua maka dikhawatirkan anak tersebut mengalami kondisi yang kurang baik, baik fisik maupun non-fisik. Selain itu pekerja sosial juga bekerja sama dengan pihak-pihak terkait sehingga permasalahan seperti ini dapat cepat terselesaikan.
Ketika mengadvokasi pengidentifikasian masalah, merumuskan gagasan dan solusi hingga tahap evaluasi kebijakan merupakan hal yang wajib dijalani dan akan berpengaruh besar kepada penyelesaian masalah tersebut, maka dalam tahap demi tahap tersebut diharapkan pekerja sosial dapat memahami pentingnya peran pekerjaan sosial dalam mengadvokasi karena advokasi sendiri merupakan salah satu langkah awal untuk suatu perubahan yang lebih baik.

\section{DAFTAR PUSTAKA}

Departemen Sosial R.I (BBPPKS) Bandung, Modul Diklat: Pekerjaan Sosial, hlm 79.

Johnson, L. C. (1995). Social work practice: A generalist approach. Boston: Allyn andBacon.

Hepworth, D.H., Rooney, R.H. \& Larsen, J.A. (1997). Direct social work practice:Theory and skills (4th Ed.). Pacific Grove, CA: Brooks/Cole.

Schneider, Robert L. \& Lester, Lori. 2001. Social Work Advocacy: A New Framework for Action. United States: Brooks/Cole Publishing Company.

Sukoco, Heru Dwi, Profesi Pekerjaan Sosial dan Proses Pertolongannya, (Bandung Koperasi Mahasiswa Sekolah Tinggi Kesejahteraan Sosial, 1991), hlm. 79-81

Taylor, E. D. (1987).From issue to action: An advocacy program model. Lancaster, PA:Family Services.

Zastrow, C. (1982). Introduction to social welfare: Institutions, social problems, servicesand current issue. New Jersey: The Dorsey Press. 